\title{
酸素を推進剤に用いたホールスラスタの研究*1 Experimental Investigation of a Hall Thruster Using Oxygen as the Propellant
}

\author{
中 川貴 史 $^{* 2 * 3} \cdot$ 山 本 直 嗣*4 小 紫 公 也*5 ·荒 川 義 博*4 \\ Takafumi Nakagawa, Naoji Yamamoto, Kimiya Komurasaki and Yoshihiro Arakawa
}

Key Words : Electric Propulsion, Hall Thruster, Oxygen

\begin{abstract}
Thrust performance and internal efficiencies of a Hall thruster using oxygen as the propellant were investigated experimentally. The thrust efficiency reached at $9 \%$ with the specific impulse of 1,000 s. The relatively poor performance is due to low propellant utilization, which is $45 \%$, in comparison with that in the case of xenon propellant. The propellant utilization increased with mass flow rate and discharge voltage. The optimum channel length for oxygen was found longer than that for xenon, which was $12 \mathrm{~mm}$. The use of BN - AlN for the channel wall results in higher propellant utilization than that of BN for channel wall.
\end{abstract}

1. は じめ に

現在の宇宙活動は全て地球を起点としたものであるため， 打ち上げのための推進斉に多くの重量を割かねばならず，必 然的にペイロードは少なくなる．このため将来的には打ち 上げに必要な推進剂重量が少ない月や宇宙ステーションを 起点とする地球から独立した宇宙活動が展開されるものと 考えられている.

この宇宙活動に月資源を利用することが古くから提唱さ れているが, 月資源の候補として最も注目されているのが 酸素である1,2). 月面の表土 (レゴリス) は各種の固体酸化 物で構成されているため, これらを還元することで酸素が 入手可能である . またクレーター内の永久暗黑域に存在す るといわれる水塊を電気分解することでも酸素が手に入る .

月製酸素を用いたミッションとしては, LEO より上の軌 道間輸送，あるいは月面を中継点とした火星等への航行等 が従来から提案されているが, 最近では地球〜LEO 間の往 復輸送における垂直離着陸型 SSTO の LEO から地球への 「帰還用酸化剂」として月製酸化剂を用いるミッションも提 案されている3) .これらのミッションでは, 月面〜月低軌道 間の輸送に月製液体酸素を酸化剂に用いた化学推進ロケッ 卜を利用し, 月低軌道からの輸送には月製酸素を推進剂に 用いた電気推進機を利用することが有効と考えられている． このミッションに最適な電気推進機として考えられてい るのがホールスラスタである.他の電気推進機と異なり, 推 進剂をジュール加熱し空気力学的に加速する機構ではなく

\footnotetext{
*1 C) 2003 日本航空宇宙学会

平成 14 年 10 月 29 日原稿受理

*2 東京大学大学院工学系研究科航空宇宙工学専攻

*3 現三菱電機 (株)

*4 東京大学大学院工学系研究科航空宇宙工学専攻

* 5 東京大学大学院新領域創成科学研究科先端エネルギー工学専攻
}

電磁気的に加速する機構であるため酸化の影響が少ないこ と，イオン加速部にグリッドを使用していないため酸素イ オンの衝突による劣化・損耗がないことから,酸素を推進剤 に用いるのに適しているといえる.ホールスラスタは, 比 推力 1000 〜 $3000 \mathrm{~s}$ で $50 \%$ を超える推進効率 (推進剂 : キセ ハン)を達成しており4)，ロシアを中心に既に 100 機以上の 宇宙機搭載実績を持っている ${ }^{5,6)}$.

酸素をホールスラスタの推進剂に用いる場合，予想され る課題として電離度の低下が考えられる. 第 1 図に示すよ うに酸素とキセノンの電離電圧はほぼ同じであるが, 電離 断面積7)には大きな差があり，酸素はキセノンに比べ電離 しにくい.

本研究では, 酸素を用いたホールスラスタで十分な性能 を得るための設計指針を得ることを目的に，推進性能と内 部効率の測定を行い，キセノンを用いた場合と比較した 。 さらにスラスタの作動パラメータが電離に与える影響を調 ベた .

\section{2. 実 験 装 置}

\section{1 ホールスラスタ}

実験には $1 \mathrm{~kW}$ 級マグネティックレイヤ型ホールスラスタ を使用した .このタイプのホールスラスタはロシアにおい て SPT (Stationary Plasma Thruster) と呼ばれるもので ある.この断面図を第 2 図に示す . このスラスタのチャンネ ル外径は $60 \mathrm{~mm}$, 幅は $5 \mathrm{~mm}$ で, チャンネル長はアノード を取り替えることで $4 \mathrm{~mm}$ から $14 \mathrm{~mm}$ まで変化させること ができる．本実験では特に言及しない限りチャンネル長は $12 \mathrm{~mm}$, チャンネル壁のセラミックの材質は $\mathrm{BN} \cdot \mathrm{AlN}$ 複 合焼結体 (BN: AlN = 4:6) である.チャンネル内にはソ レノイドコイルによって半径方向に磁場が印加される、磁 束密度は加速チャンネル内でほぼ一樣となるように設計さ 


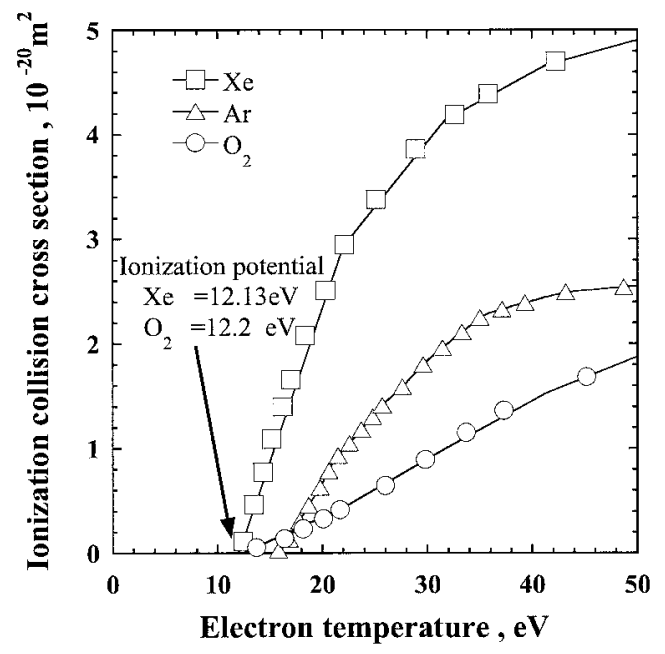

第1图 各推進斉の電離断面積 (出所 : L.J.Kieffer : Atomic data vol.1 Low-Energy Electron-Collision Cross-Section Data Part I, Academic Press ISSN)

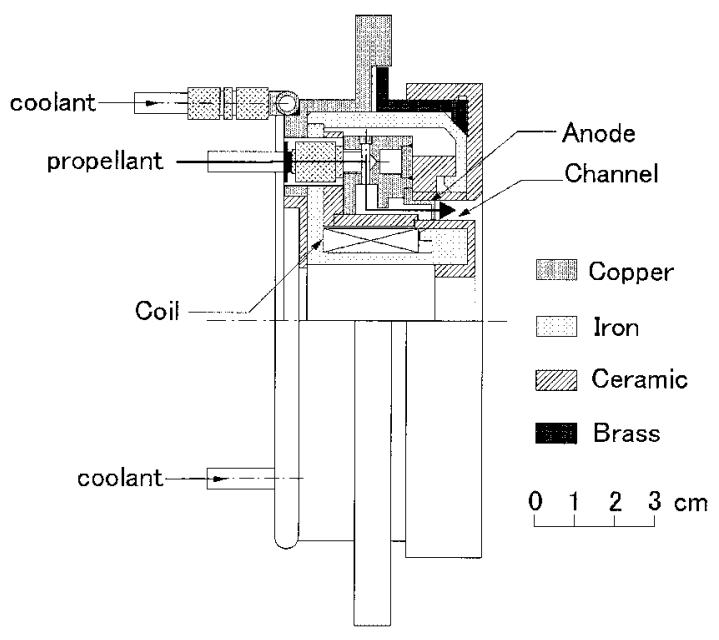

第 2 図 ホールスラスタ断面図

れており，コイル電流 $1 \mathrm{~A}$ で $0.014 \mathrm{~T}$ 程度となっている .

アノード部分は直接酸素に晒されるため, 酸化の影響を 受けやすい . 本実験では, アノード部分は水冷されている こと，作動時間が短いことから，白金被膜等の酸化対策は 行わなかった .

また，カソードにはホローカソード (イオンテック社製 7HCN-001-001) を用いているため, アノード同樣酸化に は十分注意しなければならない. 本実験中はホローカソー ドにキセノンを常に $0.27 \mathrm{mg} / \mathrm{s}$ 流したが, カソードチップ に若干の劣化が見られた。

\section{2 実験設備}

実験は直径 $0.8 \mathrm{~m}$ 長さ $2.5 \mathrm{~m}$ の真空チャンバを用いて行っ た . この真空チャンバは排気速度 $1.2 \times 10 \mathrm{~m}^{3} / \mathrm{s}$ の拡散ポ ンプ 1 台で排気しており, 到達圧力は $1.3 \times 10^{-3} \mathrm{~Pa}$ であ る . スラスタ作動時の圧力は $3.3 \times 10^{-2} \mathrm{~Pa}$ 以下であった . 推力の測定には振り子式スラストスタンド8)を用いた .

2.3 ダブルプローブ

チャンネル内の電子密度・電子温度の測定にはダブルプ

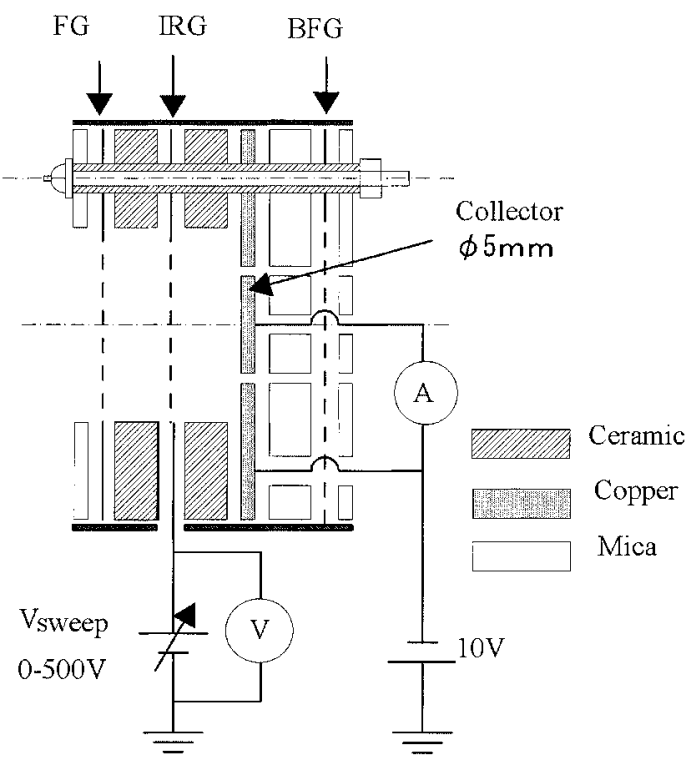

第3図 エネルギーアナライザ概略図

ローブを用いた . プローブによる擾乱を小さくするため， 本実験ではプローブをリニアモータ（オリエンタルモータ UCM640-7PU) に取り付け高速で往復させた .これによ りチャンネル内部 $7.5 \mathrm{~mm}$ までの測定においてプローブの チャンネル内滞在時間は $100 \mathrm{~ms}$ であった .

2.4 エネルギーアナライザ

本実験では第 3 図に示すエネルギーアナライザを使用し て，イオンビーム電流量・イオンエネルギー分布を測定し電 離度, イオンビームプロファイル, イオンエネルギー分布 を求めた . 2 枚目のグリッド (IRG : Ion Retarding Grid) に電圧を正に掃引することで掃引電圧以下のエネルギーを 持つイオンを追い返すことができる．コレクタには電子を 追い返すために $-10 \mathrm{~V}$ を印加した . イオンエネルギー分布 は, エネルギーアナライザをスラスタ正面に設置し , IRG に0〜+500 V まで掃引したときのコレクタに流れる電流を 測定し，これを微分することで求めた .

イオンビーム電流量及びイオンビームプロファイルは, エ ネルギーアナライザをスラスタ中心に半径 $300 \mathrm{~mm}$ でー30〜 $90^{\circ}$ 回転させ半球面積分することで求めた . 真空チャンバ 内では雰囲気ガスが存在するために, CEX (Charge Exchange : 電荷交換) が起こり, イオンビームプロファイル が宇宙空間での真のビームプロファイルと異なる . このた め IRG には+100V を印加して CEX したエネルギーの低 いイオンを捕集しないようにし，CEXしていないイオンの みを捕集し，真のビームプロファイルを求めた .このまま では実際よりもイオン電流量が少なくなるので, 中性粒子 の密度から CEX の影響を補正した 9 ）。

\section{3. 実験結果と考察}

\section{1 推進性能の測定}

放電特性を第 4 図に示す。推進斉流量は $0.33 \mathrm{mg} / \mathrm{s}$, 磁束 密度は $0.007 \mathrm{~T}$ である.比較のためにキセノンの放電特性を 


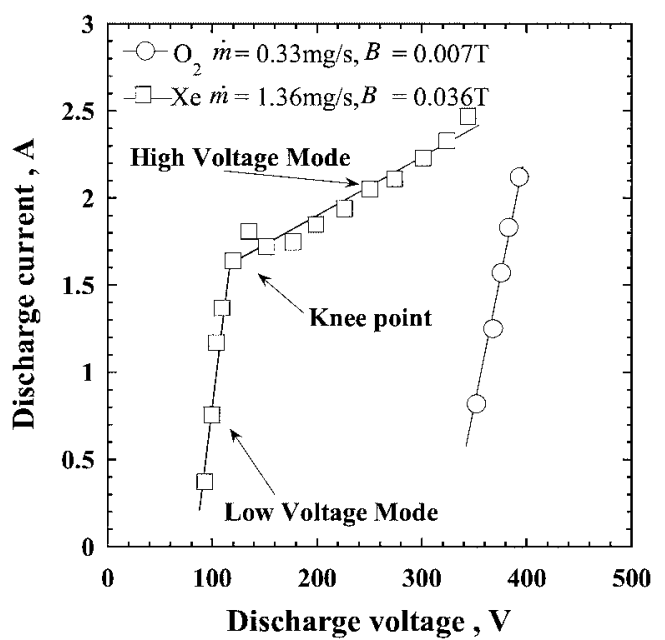

第 4 图 放電特性

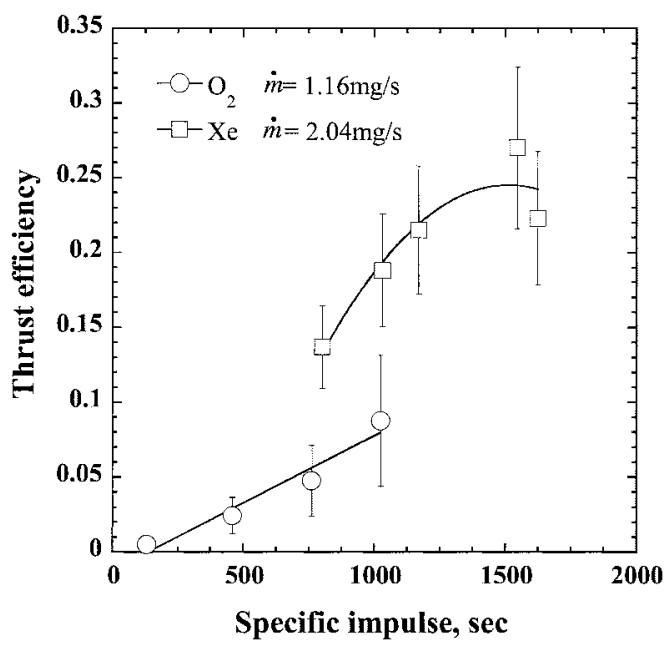

第 5 図 推進性能

示している. 推進剂流量は $1.36 \mathrm{mg} / \mathrm{s}$, 磁束密度は $0.036 \mathrm{~T}$ である、流量は 1 Aeq.で弚ろえた . 酸素の場合この流量で は磁束密度をこれ以上上げると放電を維持することができ なかった . また, 磁束密度を $0.007 \mathrm{~T}$ では放電電圧は $340 \mathrm{~V}$ から $400 \mathrm{~V}$ とキセノンと比較すると狭い範囲でしか作動し なかった . 磁束密度を下げると放電電圧 $200 \mathrm{~V}$ でも作動す るが, 放電電流が大きく最適な作動とはいえない，

一般に, ホールスラスタの放電特性には, 放電電圧が上 昇するにつれて放電電流が急増する領域 (低電圧モード) と, 放電電圧を上げても流れる放電電流がほぼ増えない領 域 (高電圧モード) が存在する . 低電圧モードは電圧の上 昇に伴い電離が促進される領域であり，高電圧モードはほ とんど電離が行われた後の領域である .この低電圧モード から高電圧モードに移行する放電特性上の点を Knee Point と呼ぶ(10). 酸素ではキセノンのような Knee Point は確認 できず，キセノンの低電圧モードに酷似した放電特性が得 られた .これは酸素が放電電圧 $400 \mathrm{~V}$ でもまだ電離が不十 分であるためと考えられる.

第 5 図に推力から測定された推進性能を示す . 推進剤流
量を酸素は $1.16 \mathrm{mg} / \mathrm{s}$ (3.5 Aeq.)，キセノンは $2.04 \mathrm{mg} / \mathrm{s}$ (1.5 Aeq.) に固定し，放電電圧を変化させて測定した . ホ ローカソードの使用限界雰囲気圧は $3.3 \times 10^{-2} \mathrm{~Pa}$ であり， 実験室の排気系の容量よりこれ以上の推進阂流量では実験 は行わなかった . また磁束密度は各放電電圧に対して最適 な点を選んでいる.なお比推力・推進効率の算出にはカソー ドに流れるキセノンの流量及びコイル, カソードの消費電 力は考慮されていない. 放電電圧 $350 \mathrm{~V}$ で推進効率 $9 \%$, こ のとき比推力 $1000 \mathrm{~s}$ が得られた . 酸素の性能がキセノンに 及ばないのは, 後述する推進剂利用効率の低さ，すなわち 電離が不十分であるためである. 放電電圧の増加に伴い推 進効率は増加しているが, これは放電電圧の増加に伴い電 子温度か増加し，推進剤利用効率か改善されたためと考え られる。

3.2 内部効率の定義

一般にホールスラスタの推進効率 $\eta_{\mathrm{t}}$ は, 以下の推進剂利 用効率 $\eta_{\mathrm{u}}$, 加速効率 $\eta_{\mathrm{a}}$, ビームエネルギー効率 $\eta_{\mathrm{e}}$, ベク トルロス補正係数 $\gamma_{\theta}$ の各内部効率の積で表すことができ $ろ^{11)}$.

$$
\begin{aligned}
\eta_{\mathrm{a}} & =\frac{I_{\mathrm{b}}}{I_{\mathrm{d}}} \\
\eta_{\mathrm{u}} & =\frac{M I_{\mathrm{b}}}{e \dot{m}} \\
\eta_{\mathrm{e}} & =\frac{\frac{1}{2} M<v_{\mathrm{i}}>^{2}}{e V_{\mathrm{d}}}=\frac{E_{\mathrm{m}}}{e V_{\mathrm{d}}}=\frac{\left\{\int f\left(E_{\mathrm{i}}\right) \sqrt{E_{\mathrm{i}}} \mathrm{d} E_{\mathrm{i}}\right\}^{2}}{e V_{\mathrm{d}}} \\
\gamma_{\theta} & =\frac{<v_{\mathrm{i}} \cos \theta_{\mathrm{b}}>}{<v_{\mathrm{i}}>} \\
\eta_{\mathrm{t}} & =\gamma_{\theta}^{2} \eta_{\mathrm{u}} \eta_{\mathrm{a}} \eta_{\mathrm{e}}
\end{aligned}
$$

ただし $I_{\mathrm{b}}$ はイオンビーム電流, $I_{\mathrm{d}}$ は放電電流, $M$ はイ オン質量, $e$ は素電荷, $\dot{m}$ は推進剂質量, $v$ は速度, $\theta_{\mathrm{b}}$ は ビームの発散角, $V_{\mathrm{d}}$ は放電電圧, $E_{\mathrm{m}}$ はイオンの平均運動 エネルギーであり $E_{\mathrm{i}}$ はイオンのエネルギーを表している.

酸素を推進剂に用いた場合，以下の電離過程が存在する.

$$
\begin{array}{ll}
\mathrm{O}_{2}+\mathrm{e}^{-} \rightarrow \mathrm{O}_{2}^{+}+2 \mathrm{e}^{-} & \text {(酸素分子の直接電離) } \\
\mathrm{O}_{2}+\mathrm{e}^{-} \rightarrow \mathrm{O}^{+}+\mathrm{O}+2 \mathrm{e}^{-} & \text {(酸素分子の解離・電離) } \\
\mathrm{O}+\mathrm{e}^{-} \rightarrow \mathrm{O}^{+}+2 \mathrm{e}^{-} & \text {(酸素原子の電離) }
\end{array}
$$

このように電界によって加速されない酸素原子 $\mathrm{O}$ が生成さ れ,さらに $\mathrm{O}^{+}$と $\mathrm{O}_{2}^{+}$が存在するため補正が必要である. この解離・電離による推力損失を考慮するために， $\alpha$ を次 のように定義する .

$$
\alpha=\frac{I_{\mathrm{b}_{-} \mathrm{O}^{+}}}{I_{\mathrm{b}}}=\frac{I_{\mathrm{b}_{-} \mathrm{O}^{+}}}{I_{\mathrm{b}_{-} \mathrm{O}^{+}}+I_{\mathrm{b}_{-} \mathrm{O}_{2}^{+}}}
$$

$F^{*}$ を解離が存在しない場合の推力とすると，解離が存在 する場合， $n, S$ を乥れ光れイオン密度，加速チャンネル面 積とすると推力 $F$ は，

$$
F=\dot{m}_{\mathrm{O}_{2}^{+}} v_{\mathrm{O}_{2}^{+}}+\dot{m}_{\mathrm{O}^{+}} v_{\mathrm{O}^{+}}
$$




$$
\begin{aligned}
& =\frac{M_{\mathrm{O}_{2}}}{e} I_{\mathrm{b}_{-} \mathrm{O}_{2}^{+}} v_{\mathrm{O}_{2}^{+}}+\frac{M_{\mathrm{O}}}{e} I_{\mathrm{b}_{-} \mathrm{O}^{+}} \sqrt{2} v_{\mathrm{b}_{-} \mathrm{O}_{2}^{+}} \\
& =\frac{M_{\mathrm{O}_{2}} v_{\mathrm{O}_{2}^{+}}}{e}\left(I_{\mathrm{b}_{-} \mathrm{O}_{2}^{+}}+I_{\mathrm{b}_{-} \mathrm{O}^{+}} / \sqrt{2}\right)
\end{aligned}
$$

イオンビーム電流量 $I_{\mathrm{b}}$ は，

$$
I_{\mathrm{b}}=I_{\mathrm{b}_{-} \mathrm{O}_{2}^{+}}+I_{\mathrm{b}_{-} \mathrm{O}^{+}}
$$

よって推力は，

$$
\begin{aligned}
F & =\left\{1+\left(\frac{1}{\sqrt{2}}-1\right) \alpha\right\} \frac{1}{e} I_{\mathrm{b}} M_{\mathrm{O}_{2}} v_{\mathrm{O}_{2}^{+}} \\
& =\left\{1+\left(\frac{1}{\sqrt{2}}-1\right) \alpha\right\} \frac{\gamma_{\theta} I_{\mathrm{b}} \sqrt{2 M_{\mathrm{O}_{2}} E_{\mathrm{m}}}}{e} \\
& =\left\{1+\left(\frac{1}{\sqrt{2}}-1\right) \alpha\right\} F^{*}
\end{aligned}
$$

のように書ける．したがって，解離による補正係数は，

$$
\gamma_{\mathrm{d}}=1+\left(\frac{1}{\sqrt{2}}-1\right) \alpha
$$

と表され，推進効率は次のように書ける .

$$
\eta_{\mathrm{t}}=\gamma_{\mathrm{d}}^{2} \gamma_{\theta}^{2} \eta_{\mathrm{u}} \eta_{\mathrm{a}} \eta_{\mathrm{e}}
$$

\section{3 内部効率の測定}

内部効率の測定において, 推進阂は酸素で流量 $1.16 \mathrm{mg} / \mathrm{s}$, 磁束密度 $0.014 \mathrm{~T}$, キセノンで流量 $2.04 \mathrm{mg} / \mathrm{s}$, 磁束密度 $0.036 \mathrm{~T}$ とした .

まず，解離による損失を見積もつた. $\mathrm{O}^{+}$及び $\mathrm{O}_{2}^{+}$の連 続式は以下のようになる .

$$
\begin{aligned}
n_{\mathrm{O}_{2}^{+}} v_{\mathrm{O}_{2}^{+}}= & \int_{V}\left\langle\sigma v_{\mathrm{e}}\right\rangle_{\mathrm{O}_{2} \rightarrow \mathrm{O}_{2}^{+}} N_{\mathrm{e}} N_{\mathrm{O}_{2}} \\
n_{\mathrm{O}^{+}} v_{\mathrm{O}^{+}}= & \int_{V}\left\langle\sigma v_{\mathrm{e}}\right\rangle_{\mathrm{O}_{2} \rightarrow \mathrm{O}^{+}} N_{\mathrm{e}} N_{\mathrm{O}_{2}} \\
& +\int_{V}\left\langle\sigma v_{\mathrm{e}}\right\rangle_{\mathrm{O} \rightarrow \mathrm{O}^{+}} N_{\mathrm{e}} N_{\mathrm{O}}
\end{aligned}
$$

\section{$V$ は電離領域体積}

よって,(2) 式で定義された $\alpha$ は以下のように見積もった この算出のため, 電離領域の電子温度, 電子密度, イオン 生成領域を測定した .

$\alpha=\frac{I_{\mathrm{O}^{+}}}{I_{\mathrm{O}^{+}}+I_{\mathrm{O}_{2}^{+}}}=\frac{n_{\mathrm{O}^{+}} v_{\mathrm{O}^{+}}}{n_{\mathrm{O}_{2}^{+}} v_{\mathrm{O}_{2}^{+}}+n_{\mathrm{O}^{+}} v_{\mathrm{O}^{+}}}$

$=\frac{\int_{V}\left\langle\sigma v_{\mathrm{e}}\right\rangle_{\mathrm{O}_{2} \rightarrow 0^{+}} N_{\mathrm{e}} N_{\mathrm{O}_{2}}+\int_{V}\left\langle\sigma v_{\mathrm{e}}\right\rangle_{0 \rightarrow 0^{+}} N_{\mathrm{e}} N_{\mathrm{O}}}{\int_{V}\left\langle\sigma v_{\mathrm{e}}\right\rangle_{\mathrm{O}_{2} \rightarrow \mathrm{O}_{2}^{+}} N_{\mathrm{e}} N_{\mathrm{O}_{2}}+\int_{V}\left\langle\sigma v_{\mathrm{e}}\right\rangle_{\mathrm{O}_{2} \rightarrow 0^{+}} N_{\mathrm{e}} N_{\mathrm{O}_{2}}+\int_{V}\left\langle\sigma v_{\mathrm{e}}\right\rangle_{0 \rightarrow 0^{+}} N_{\mathrm{e}} N_{\mathrm{O}}}$ $\approx \frac{\left\langle\sigma v_{\mathrm{e}}\right\rangle_{\mathrm{O}_{2} \rightarrow \mathrm{O}_{2}^{+}} N_{\mathrm{e}} N_{\mathrm{O}_{2}} S L+\left\langle\sigma v_{\mathrm{e}}\right\rangle_{\mathrm{O} \mathrm{O}^{+}} N_{\mathrm{e}} N_{0} S L}{\left\langle\sigma v_{\mathrm{e}}\right\rangle_{\mathrm{O}_{2} \rightarrow \mathrm{O}^{+}} N_{\mathrm{e}} N_{\mathrm{O}_{2}} S L+\left\langle\sigma v_{\mathrm{e}}\right\rangle_{\mathrm{O}_{2} \rightarrow \mathrm{O}_{2}^{+}} N_{\mathrm{e}} N_{\mathrm{O}_{2}} S L+\left\langle\sigma v_{\mathrm{e}}\right\rangle_{0 \rightarrow 0^{+}} N_{\mathrm{e}} N_{0} S L}$ $\approx \frac{\left\langle\sigma v_{\mathrm{e}}\right\rangle_{\mathrm{O}_{2} \rightarrow \mathrm{O}_{2}^{+}}+\left\langle\sigma v_{\mathrm{e}}\right\rangle_{\mathrm{O} \rightarrow \mathrm{O}^{+}}\left\langle\sigma v_{\mathrm{e}}\right\rangle_{\mathrm{O}_{2} \rightarrow \mathrm{O}^{+}} N_{\mathrm{e}} L / v_{\mathrm{O}_{2}}}{\left\langle\sigma v_{\mathrm{e}}\right\rangle_{\mathrm{O}_{2} \rightarrow \mathrm{O}^{+}}+\left\langle\sigma v_{\mathrm{e}}\right\rangle_{\mathrm{O}_{2} \rightarrow \mathrm{O}_{2}^{+}}+\left\langle\sigma v_{\mathrm{e}}\right\rangle_{\mathrm{O} \rightarrow \mathrm{O}^{+}}\left\langle\sigma v_{\mathrm{e}}\right\rangle_{\mathrm{O}_{2} \rightarrow \mathrm{O}^{+}} N_{\mathrm{e}} L / v_{\mathrm{O}_{2}}}$

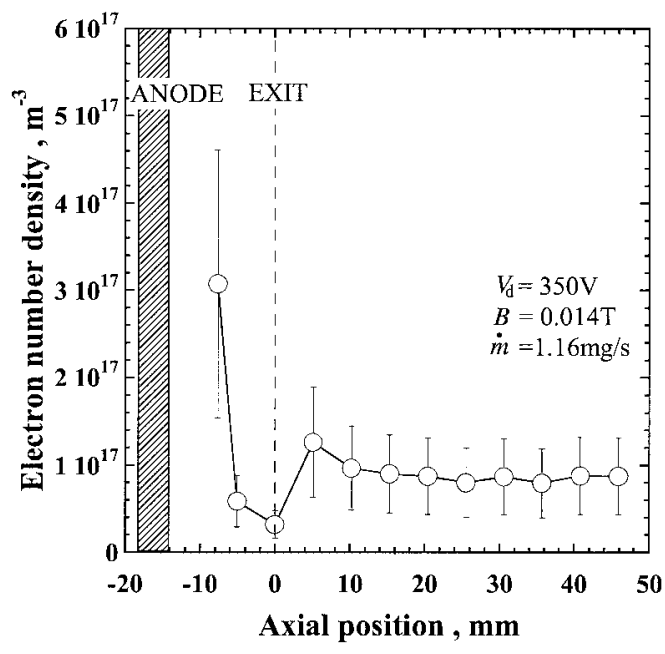

第6 图 電子密度分布

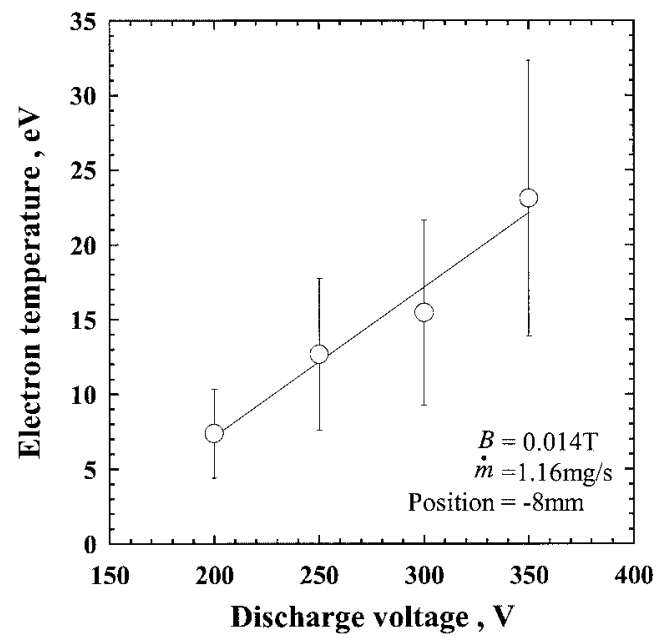

第7图 アノードから $4 \mathrm{~mm}$ の点における電子温度

ダブルプローブから得られた電子密度のスラスタ軸方向 分布を第 6 図に示す.このように電子密度はスラスタ出口 から約 $8 \mathrm{~mm}$ 上流の点で急増するため，これより上流がイ オン生成領域であると見なし，電離領域の長さを $4 \mathrm{~mm}$ と した . またスラスタ出口から $8 \mathrm{~mm}$ の点における電子温度 及び電子密度を電離領域の電子温度及び電子温度として $\alpha$ を算出するのに用いた (第 7 図) .このとき $\alpha$ は $0.15 \sim 0.3$ となり，(3) 式から解離による損失 $1-\gamma_{\mathrm{d}}^{2}$ は第 8 図のよう に10〜25\%とわかった .

エネルギーアナライザを用いて算出した酸素とキセノン の推進剂利用効率及び加速効率を第 9,10 図に光れ光れ示 す . 推進剂利用効率は放電電圧の増加に伴い増加している。 これは第 7 図に示すとおり, 放電電圧の増加に伴い電子温 度が上昇し，電離断面積か増加するためである .キセノンが ほぼ $100 \%$ に達するのに対して酸素は最も電圧の高い $350 \mathrm{~V}$ でも $45 \%$ であった .これは電離断面積の差か推進剂利用効 率の差となって現れたものと考えられる . また加速効率は キセノンで $50 \%$,酸素では $35 \%$ となった .

酸素での加速効率がキセノンよりも劣るのは, 印加磁束 


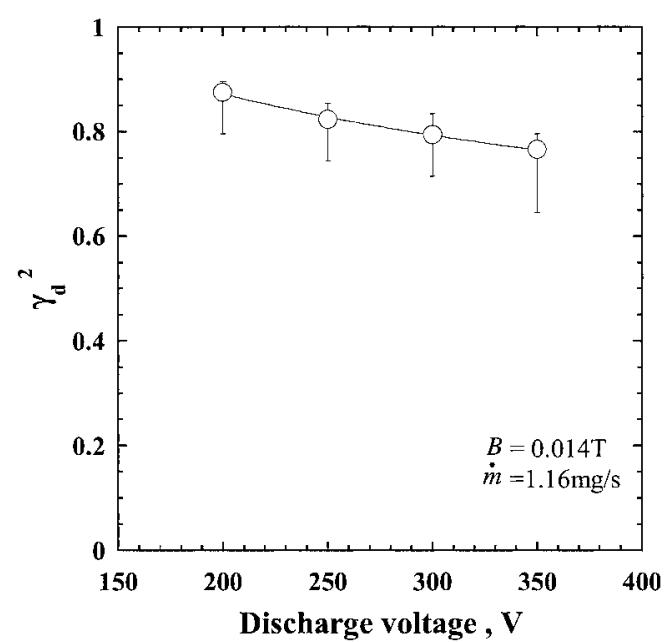

第 8 図 解離による損失

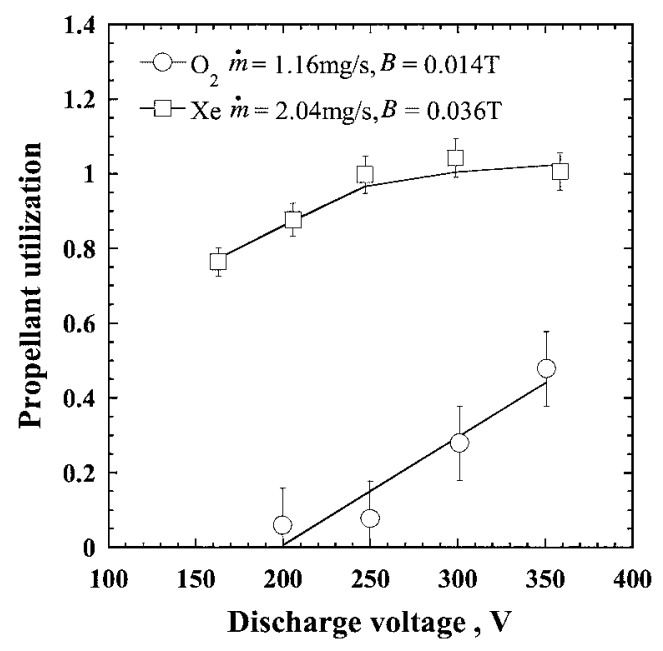

第 9 図 推進剂利用効率

密度がキセノンでの磁束密度よりも低く, 電子が流れやす いためである . 磁束密度を上げると放電電圧の作動範囲は 狭くなるが, 酸素でも磁束密度を $0.017 \mathrm{~T}$ にすることで加速 効率 $60 \%$ を達成した .このときの推進斉利用効率は $34 \%$ で あった。

酸素とキセノンのイオンエネルギー分布を第 11 図に， ビームエネルギー効率を第 12 図に示す . ビームエネルギー 効率の值はキセノンと酸素でほとんど差はないが, イオン エネルギー分布関数は全く異なった . 酸素のイオンエネル ギー分布は, ピークが放電電圧に近いことから大部分のイ オンはポテンシャルの高いアノード近辺で生成されている と思われる. しかし推進剂利用効率の結果からもわかると おり，チャンネル内にはまだ多くの中性粒子が存在するた め, これがチャンネル内全体で電離するため, ポテンシャ ルの低い領域でも電離が起こり，結果的にエネルギーが低 いイオンが存在すると思われる . 放電電圧を上げるほど電 子温度が増加し，ポテンシャルの低い場所で生成されるイ オンか増加し, ビームエネルギー効率は減少すると考えら れる。

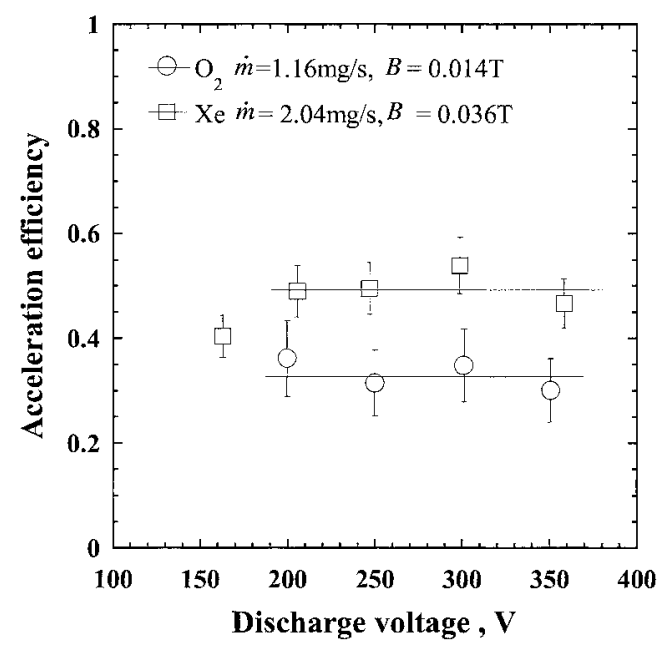

第 10 図 加速効率

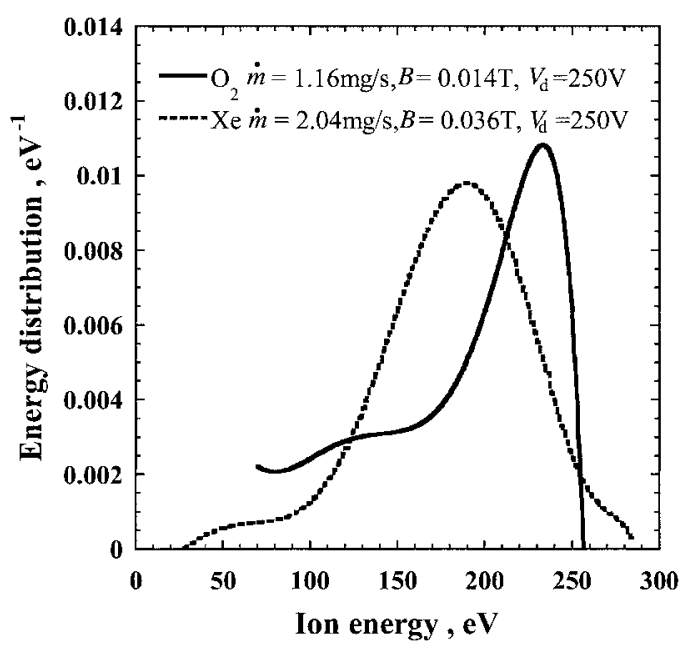

第11図 イオンエネルギー分布

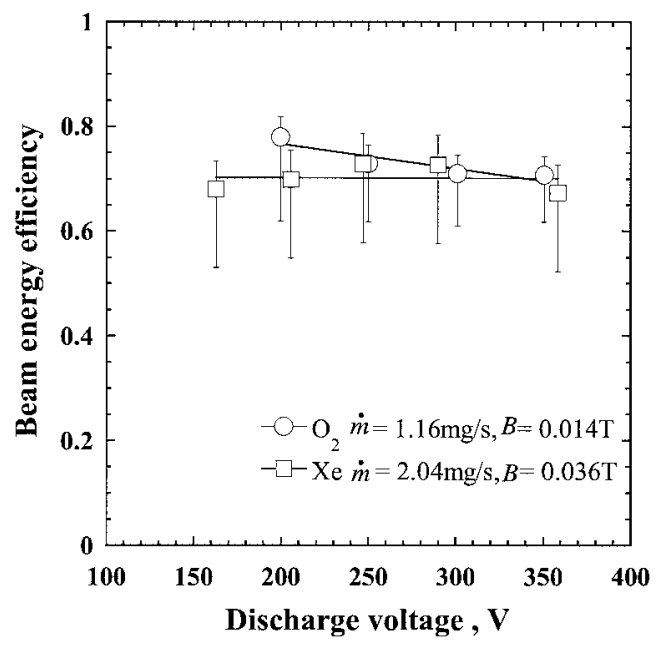

第 12 図 ビームエネルギー効率

一方, キセノンもアノード付近で電離しているが, チャ ンネルが長いため電離したイオンがチャンネル壁に衝突し て中性粒子に戻ってしまう．ところがキセノンは電離しや すいためチャンネル内で再び電離が行われる .このため酸 


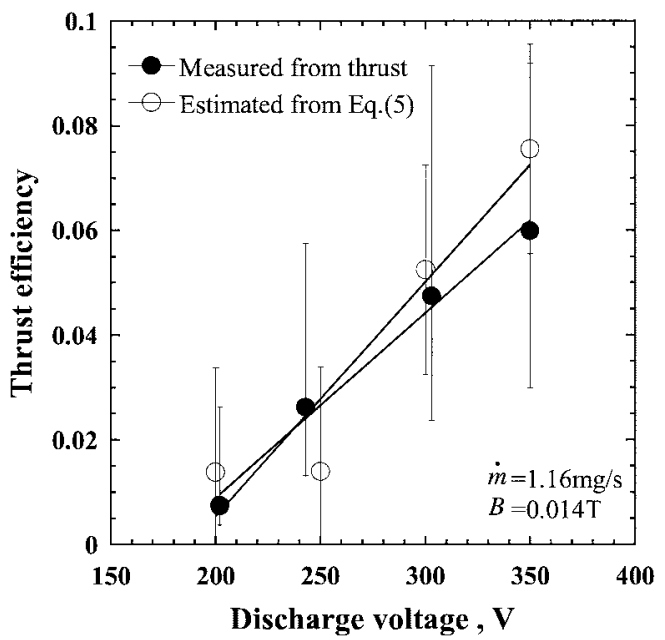

第 13 図 推力から実測した推進効率と内部効率の積

素よりもピークが低くなったと考えられる．

発散角としてイオンビームの半値半幅を用いたところ, 酸 素とキセノンの発散角はほぼ同じで10〜15になった .こ のため発散によるべクトルロスはキセノン同樣 $5 \%$ 以下に なりほぼ無視できる.推進剤による相違が見られなかった のはビームプロファイルがチャンネル内の電界形状によっ て決まり，電界形状は磁場形状等によるがキセノンと酸素 で光れほど差がなかったためと思われる .

第 13 図は, 内部効率の積で求まる推進効率と推力から 実測した推進効率の比較である.ほぼ一致していることか ら，これまでの内部効率の見積りが妥当であったといえる。

\section{4 推進剂利用効率の改善}

内部効率の測定からキセノンと比較して酸素での推進性 能が低下する要因として推進斉利用効率，解離による損失， 加速効率の低下が考えられる. しかし解離による損失や加 速効率の低下はせいぜい 2 割程度であるのに対して推進剂 利用効率の低下は 6 割と非常に大きい.ゆえに推進性能の 向上には推進剤利用効率の改善が最も有効である. 弚こで 推進斉流量, チャンネル長, チャンネル壁材質を変化させ ることで推進剤利用効率にどのような影響を与えるかを調 ベた .

第 14 図は推進剂流量を変化させたときの推進剂利用効 率の変化を示したものである. 磁束密度は $0.014 \mathrm{~T}$ である. 推進剂流量を増加させるほど推進剂利用効率は向上した . これは推進剂流量を上げることでチャンネル内の中性粒子 密度か増加し, 電離度か増加したためと考えられる。

チャンネル長を変化させたときの推進剂利用効率の変化 を第 15 図に示す．磁束密度は $0.008 \mathrm{~T}$ である .チャンネル 長が 4 〜 $12 \mathrm{~mm}$ まではチャンネル長が長くなるほど推進剂 利用効率が向上するが, $12 \mathrm{~mm}$ で最大值となる結果が得ら れた .これはチャンネル長が長くなると, チャンネル内で 中性粒子と電子が衝突する確率か増えるため生成するイオ ンの量は増えるが, 同時に生成したイオンがチャンネル壁 面に衝突して中性粒子に戻るイオン損失も増えるためだと 考えられる12)

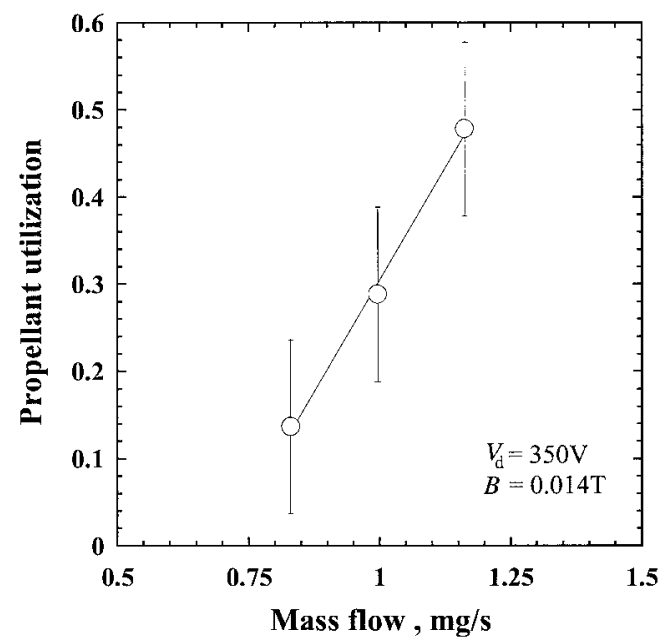

第 14 図 推進剂流量と推進剂利用効率の関係

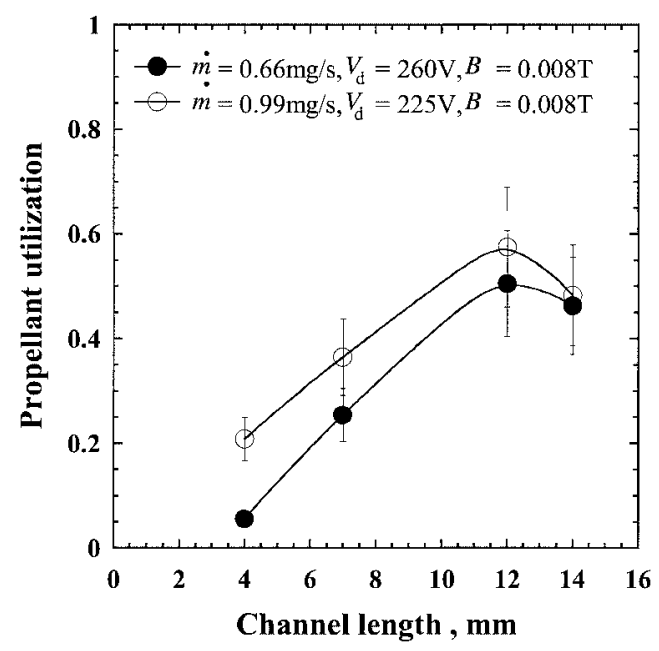

第 15 図 チャンネル長と推進剂利用効率の関係

チャンネル長の最適值が $12 \mathrm{~mm}$ とキセノンよりも長い

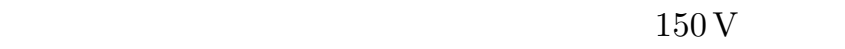
子温度は $10 \mathrm{eV}$ であり，電離断面積から求まる中性粒子の 平均自由行程はおよ兰 $0.5 \mathrm{~mm}$ 程度となる.一方, 酸素は 電子温度が $25 \mathrm{eV}$ の場合でも平均自由行程は $9 \mathrm{~mm}$ になる。 このためチャンネル長の最適值がキセノンよりも長くなっ たと考えられる

チャンネル壁面の材質を $\mathrm{BN} \cdot \mathrm{AlN}$ と BN とで比較した ところ, BN では放電振動が非常に激しくなり, 酸素で安定 に作動することはできなかった .このため酸素よりは電離 しやすいアルゴン (第 1 図参照) を用いて推進剂利用効率 を測定した . 測定結果を第 16 図に示す．このようにBN・ AlN を用いた場合の方がBN を用いた場合よりも，推進剤 利用効率が高く，電離がより行われていることがわかった . これは 2 次電子放出係数が電離に大きく影響しているため であると考えられる ${ }^{13 \sim 17)}$. すなわちエネルギーの高い電子 がシースのポテンシャルを超えて壁面に衝突すると壁面か ら電子が飛び出す．この飛び出した電子はシースのポテン シャル程度のエネルギーしか持たない．よって 2 次電子放 


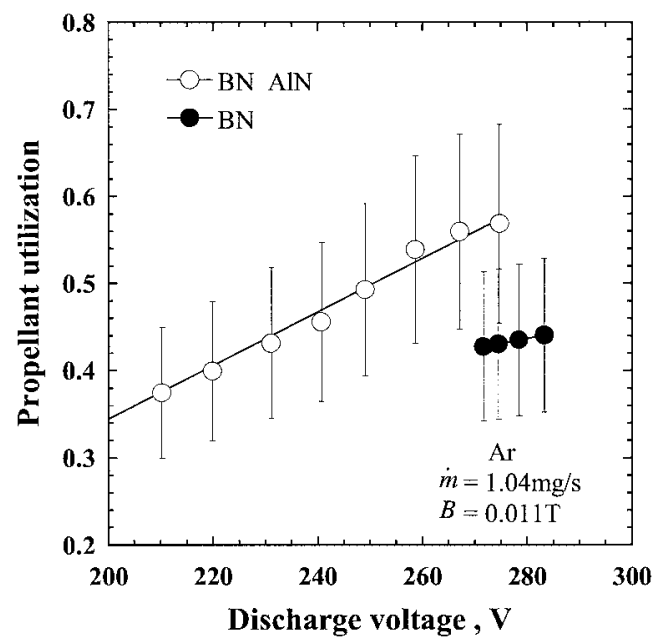

第 16 図 チャンネル壁材質と推進剂利用効率の関係 (推進剂 : アル ゴン)

第 1 表 $\mathrm{BN}$ と $\mathrm{BN} \cdot \mathrm{AlN}$ の 2 次電子放出係数 (衝突電子の エネルギー : $10 \mathrm{eV}$ )

\begin{tabular}{cc}
\hline セラミック材質 & 2 次電子放出係数 \\
\hline $\mathrm{BN} \cdot \mathrm{AlN}$ & 0.33 \\
$\mathrm{BN}$ & 0.76 \\
\hline
\end{tabular}

出係数の大きい材質を用いると, プラズマ中には電離に大 きく寄与するエネルギーの高い電子が減り, シースのポテ ンシャル程度のエネルギーを持った電子か増加する . 結果 として，電離度が低下すると考えられる. $\mathrm{BN}$ は $\mathrm{BN} \cdot \mathrm{AlN}$ 複合焼結材よりも 2 次電子放出係数が大きい18) (第 1 表) ため電離しにくく，酸素では作動しなかったと考えられる． また 2 次電子放出係数のより小さい物質を壁面に使用する ことによりさらなる推進剂利用効率の向上が見込まれる .

$$
\text { 4. ま と め }
$$

酸素を推進剂として用いて $1 \mathrm{~kW}$ 級ホールスラスタの安 定作動に成功した .さらに以下のことがわかった .

1) キセノンを推進剤として用いた場合よりは狭いがある 程度広い範囲での作動を確認し, 最大で推進効率 $9 \%$, 比 推力 $1000 \mathrm{~s}$ を得た。

2) 内部効率を測定し, 推進剂利用効率 $45 \%$, 加速効率 $35 \%$ ，ビームエネルギー効率 $75 \%$ を得た .さらに解離電離 の影響による効率の低下は $20 \%$ と見積もられた .これより 酸素での低い推進効率の最大の要因は低い推進剂利用効率 であることがわかった .

3) 推進剂利用効率の向上には放電電圧, 推進剂流量だけ
でなくチャンネル長さやチャンネル壁材質も考慮する必要 がある .

\section{参 考 文 献}

1) Hepp, A. F.: Production and Use of Metals and Oxygen for Lunar Propulsion, J. Propul. Power, 10 (1994), pp. 834-840.

2) Rosenberg, S. D.: Concepts in Lunar Resource Utilization, AIAA Paper 91-2446, 1991.

3) 長島隆一: 推進薬 (LOX) 製造を核とする月面産業の成立性に 関する研究, 博士論文, 東京大学, 1998 .

4) Garkusha, V., Lukiaschenko, V., Semenkin, A., Tverdokhlebov, S., Kim, V., Popov, G., Maslennikov, N. and Murashko, V. : Modern Status of Hall Thrusters Development in Russia, AIAA Paper 99-2157, 1999.

5) Kim, V., Popov, G., Arkhipov, B., Murashko, V., Gorshkov, O., Koroteyev, A., Garkusha, V., Semenkin, A. and Tverdokhlebov, S.: Electric Propulsion Activity in Russia, IEPC Paper 01-005, 2001.

6) Kim, V., Popov, G., Tikhonov, V., Garkusha, V. and Murashko, V.: Modern Trends of Electric Propulsion Activity in Russia, IEPC Paper 99-004, 1999.

7) Kieffer, L. J.: Atomic Data, Vol.1, Low-Energy ElectronCollision Cross-Section Data Part I, Academic Press.

8) Sasoh, A. and Arakawa, Y.: A High Resolution Thrust Stand for Ground Tests of Low-Thrust Space Propulsion Devices, Rev. Sci. Instrum., 64 (1993), pp. 719-723.

9) Kusamoto, D., Mikami, K., Komurasaki, K. and Gallimore, A. D.: Exhaust Beam Profiles of Hall Thrusters, Trans. Jpn. Soc. Aeronaut. Space Sci., 40 (1998), pp. 238-247.

10) Hargus, W. A., Jr., Meezan, N. B. and Cappelli, M. A.: The Transient Behavior of a Low Power Laboratory Xenon Hall Thruster, AIAA Paper 97-3050, 1997.

11) Komurasaki, K. and Arakawa, Y.: Two-Dimensional Numerical Model of Plasma Flow in a Hall Thruster, J. Propul. Power, 11 (1995), pp. 1317-1323.

12) Kusamoto, D., Mikami, K. and Komurasaki, K.: Channel Length and Thruster Performance of Hall Thrusters, AIAA Paper 96-3194, 1996.

13) Morozov, A. I. and Shubin, A. P.: Electron Kinetics in the Wall-Conductivity Regime I, II, Sov. J. Plasma Phys., 10 (1984), pp. 728-735.

14) Morozov, A. I. and Shubin, A. P.: Analytic Methods in the Theory of Near-Wall Conductivity I, II, Sov. J. Plasma Phys., 16 (1990), pp. 711-715.

15) Bugrova, A. I., Morozov, A. I. and Khartchevnikov, V. K.: Experimental Investigation of Near Wall Conductivity, Sov. J. Plasma Phys., 16 (1990), pp. 849-856.

16) Jolivet, L. and Roussel, J. F.: Effects of the Secondary Electronic Emission on Sheath Phenomena in a Hall Thruster, The 3rd International Conference on Spacecraft Propulsion, Cannes, 2000.

17) Makowski, K., Peradzynski, Z., Barral, S. and Dudeck, M.: Influence of the Plasma-Wall Interactions on the Operation of Hall Thrusters, The 3rd International Conference on Spacecraft Propulsion, Cannes, 2000.

18) Locke, S., Shumlak, U. and Fife, J. M.: A Numerical Study of the Effect of Channel Insulator Discontinuity on Hall Thruster Discharge, IEPC Paper 01-23, 2001. 